\title{
Analisis Kriteria dan Bobot untuk Penentuan Lokasi Jalan Pertanian di Provinsi Jambi
}

\author{
Criteria and Weight Analysis in Determining Location of Agricultural Roads in Jambi Province
}

\author{
Asnelly Ridha Daulay \\ Badan Penelitian dan Pengembangan Daerah Provinsi Jambi \\ Email: asnelly_daulay@jambiprov.go.id
}

Diterima: 18 Desember 2018; Disetujui: 24 Juli 2019

\begin{abstract}
ABSTRAK
Jalan pertanian sangat dibutuhkan untuk lalu lintas pengangkutan sarana produksi pertanian dan hasil panen. Namun, proses seleksi lokasi untuk pembangunan jalan tersebut dilakukan secara subjektif, tanpa kriteria yang baku dan kerap dilatari kepentingan politis. Penelitian ini bertujuan menggali kondisi eksisting pembangunan jalan pertanian di Provinsi Jambi, termasuk gambaran partisipasi masyarakat untuk merawat jalan tersebut, serta menyusun kriteria dan bobotnya masing-masing untuk penentuan lokasi pembangunan jalan pertanian. Pengumpulan data dilakukan melalui observasi, wawancara mendalam, serta studi pakar. Data-data ini kemudian dianalisis menggunakan Simple Multi Attribute Rating Technique (SMART). Hasil penelitian menunjukkan bahwa terdapat delapan masalah utama terkait jalan pertanian di Provinsi Jambi yaitu konstruksi model, perawatan, pemanfaatan, konektivitas, pendanaan, alih fungsi lahan pertanian, daya tahan, dan pola pengerjaan jalan pertanian. Terdapat 4 kriteria yang dikembangkan sebagai pertimbangan dalam menentukan lokasi jalan pertanian dengan bobot masing-masing sebagai berikut: lokasi $(0,23)$, kelembagaan/kelompok tani $(0,36)$, kualifikasi kebun/sawah $(0,24)$ dan sharing perawatan jalan pertanian $(0,17)$.
\end{abstract}

Kata kunci: jalan pertanian; alih fungsi lahan; fasilitas produksi; partisipasi masyarakat

\section{ABSTRACT}

Agricultural roads are urgently needed for the transportation of agricultural production's tools and yield. However, the site selection process for the construction of the road was carried out subjectively, without standard criteria and often based on political interests. This study aims to explore the existing conditions of agricultural road's development in Jambi Province, including the description of community participation to maintain the road and develop some criteria and weighting of each for determining the location. Primary data collected through observation, indepth interview and expert judgments. Those data then was analysed using Simple Multi Attribute Rating Technique (SMART). The results showed that eight prominent problems were found related to agricultural roads in Jambi Province, namely the model construction, maintenance, utilization, connectivity, funding, agricultural land conversion, durability, and project scheme. Four criterias are stipulated as the consideration to determine location of the road with the respective of their weights i.e. location (0.23), institutional/farmer group (0.36), qualification of the plantation / rice field (0.24) and sharing to maintenance the agricultural road (0.17).

Keywords: agricultural road; community participation; land conversion; production facilities

\section{PENDAHULUAN}

Keterbatasan infrastruktur pertanian merupakan salah satu kendala besar yang menyebabkan petani kesulitan meningkatkan produksi pertanian dan memasarkannya. Pada umumnya minimnya pendanaan menjadi alasan belum terbangunnya infrastruktur tersebut. Pembangunan infrastruktur seharusnya melibatkan pihak swasta. Namun, tidak semua jenis infrastruktur diminati oleh pihak swasta untuk berinvestasi, khususnya infrastruktur di bidang pertanian, sehingga peran pemerintah sangat diharapkan dapat mewujudkannya. Selain faktor keterbatasan biaya, pendekatan terpadu kepada masyarakat mengenai pembangunan infrastruktur yang dimulai dari perencanaan hingga pelayanannya juga perlu untuk dilakukan sehingga pemanfaatannya dapat berjalan secara optimal dalam mendukung ekonomi masyarakat.

Jalan pertanian atau disebut juga jalan produksi dan jalan usaha tani merupakan salah satu jenis infrastruktur yang dibutuhkan di pedesaan. Jalan pertanian menurut Hardaningrum (2015) adalah kategori jalan khusus guna mendukung kegiatan agribisnis. Jalan produksi adalah prasarana transportasi pada kawasan pertanian untuk memperlancar pengangkutan sarana produksi menuju lahan pertanian/perikanan dan mengangkut hasil produk dari lahan menuju pemukiman, tempat penampungan sementara/ pengumpulan atau tempat lainnya. Menurut Siregar dan Hasanah (2011), jaringan infrastruktur yang baik menjadi faktor penentu bagi pertumbuhan, memperbaiki ketimpangan pendapatan dan mengurangi kemiskinan. Dari sisi ekonomi mikro, infrastruktur juga menjadi elemen penunjang mobilitas manusia sebagai agen ekonomi mulai dari proses produksi, distribusi, dan konsumsi serta memfasilitasi aliran input. Pengembangan infrastruktur yang ekstensif dan efisien merupakan faktor penentu berjalannya fungsi perekonomian secara efektif. Infrastruktur yang berkualitas menjembatani perbedaan jarak antar wilayah, mengintegrasikan pasar domestik dan menghubungkan pasar domestik dan internasional dengan biaya yang rendah. Menurut Tarigan dan Syumanjaya (2013), infrastuktur jalan merupakan lokomotif penggerak pembangunan ekonomi perkotaan dan pedesaan serta pilar penentu kelancaran arus barang, jasa, manusia, uang dan informasi dari satu zona pasar ke zona pasar lainnya. 
Hasil penelitian di berbagai negara mengungkapkan tentang infrastruktur jalan di pedesaan. Dercon (2005) mengemukakan keterbatasan akses terhadap infrastruktur mempersulit rumah tangga petani untuk keluar dari kemiskinan. Namun, pengentasan kemiskinan tidak selamanya berarti telah terjadi perbaikan distribusi pendapatan sebab pertumbuhan ekonomi dan pengentasan kemiskinan yang luar biasa terjadi di Indonesia dan China sejak akhir 1970-an, telah memunculkan ketidaksetaraan masalah sosioekonomi di Indonesia pada era 1990-an yang semakin serius dari waktu ke waktu. Hasil penelitian Zhang et al. (2017) di China menunjukkan perbaikan infrastruktur jalan berkorelasi negatif dengan pangsa pendapatan tenaga kerja. Infrastruktur jalan mengarah pada perluasan pasar dan membantu mempromosikan mobilitas dan kekuatan/daya tawar modal, meningkatkan bagian pendapatan modal, terutama di bawah sistem berlaku di China saat ini yang menghambat mobilitas tenaga kerja. China tengah berada pada era industrialisasi yang diperkuat oleh pengembangan infrastruktur jalan, yang berkontribusi terhadap penurunan porsi pendapatan tenaga kerja yang terkait dengan transformasi struktural. Dapat disimpulkan bahwa infrastruktur jalan membantu meningkatkan pangsa tenaga kerja dan karena itu mengurangi kesenjangan pendapatan di China.

Dampak jalan beraspal di desa dilaporkan Aggarwal (2018) di India yang menunjukkan bukti yang konsisten berupa (a) pengurangan harga barang kebutuhan terutama yang diproduksi di kota; (b) peningkatan variasi konsumsi barang-barang kebutuhan terutama yang tidak diproduksi di desa tersebut; (c) peningkatan penggunaan pupuk dan bibit hibrid; (d) meningkatkan jumlah anak-anak yang mendaftar ke sekolah; dan (e) menarik lebih banyak wanita dan remaja usia sekolah untuk bergabung sebagai angkatan kerja.

Penelitian yang dilaksanakan di beberapa wilayah di Indonesia juga mengungkap hal-hal penting terkait jalan pertanian. Hardaningrum (2015) mengatakan bahwa jalan produksi memberi: (a) manfaat langsung berupa kemudahan distribusi material budidaya, pengangkutan hasil panen serta membuka keterisoliran daerah pesisir; (b) manfaat tidak langsung berupa peningkatan pendapatan petani tambak, kemudahan dalam upaya pengawasan lokasi budidaya, penghematan biaya transportasi, dan peningkatan nilai jual produk perikanan; dan (c) manfaat tidak kentara berupa meningkatnya intensivitas pengawasan dan pemantauan proses budidaya oleh pemilik tambak serta penyuluh perikanan dan koneksitas antar lokasi budidaya semakin kuat sehingga memungkinkan terjadinya interaksi sosial antar pelaku usaha perikanan. Menurut Posumah (2015) yang melakukan analisis pengaruh pembangunan infrastruktur terhadap investasi di Kabupaten Minahasa Tenggara menyimpulkan bahwa variabel infrastruktur pertanian berpengaruh secara signifikan terhadap investasi, sedangkan variabel infrastruktur kesehatan dan pendidikan tidak berpengaruh terhadap investasi. Hasil penelitian Tarigan dan Syumanjaya (2013) di Kecamatan Dolok Silau Kabupaten Simalungun Sumatera Utara menyimpulkan bahwa: (1) semakin baik kualitas infrastruktur, maka semakin sedikit biaya transportasi yang ditanggung oleh petani; (2) semakin baik kualitas infrastruktur, maka semakin banyak petani yang memasarkan hasil-hasil pertaniannya secara langsung ke pasar, sehingga semakin banyak para tengkulak memasuki desa dan harga menjadi bersaing; dan (3) semakin buruk kualitas infrastruktur maka semakin tinggi harga hasil-hasil pertanian yang dapat diperoleh para petani.

Pembangunan jalan pertanian di lingkungan persawahan dan perkebunan milik rakyat di Provinsi Jambi telah dimulai sejak tahun 2000-an yang didanai lewat APBN. Beberapa tahun belakangan jalan pertanian didanai oleh APBD Provinsi Jambi dan APBD Kabupaten. Persoalan muncul ketika proses seleksi untuk menentukan lokasi pembangunan jalan pertanian seringkali dipengaruhi oleh kepentingan politik dari pemimpin daerah maupun anggota legislatif terutama menjelang dilakukannya pemilihan umum.

Pembangunan jalan pertanian harus berdasarkan proposal, namun belum terdapat kriteria penilaian yang baku untuk memilih lokasi pembangunan jalan yang tepat. Berdasarkan latar belakang tersebut, penelitian ini akan menggali gambaran sekarang jalan pertanian di Provinsi Jambi serta penentuan kriteria yang tepat dan pembobotannya sehingga penentuan lokasi jalan pertanian menjadi tepat sasaran.

\section{METODE PENELITIAN}

Penelitian ini dilaksanakan di 5 kabupaten/Kota di Provinsi Jambi (Tebo, Sarolangun, Tanjung Jabung Timur, Kabupaten Kerinci dan Kota Sungai Penuh), dimulai bulan April sampai Juli 2018. Data primer diperoleh melalui observasi kondisi jalan pertanian, FGD dengan perwakilan kelompok tani, IDI (in depth interview) dengan narasumber terpilih yang mememiliki pengalaman kerja menangani jalan pertanian serta pengisian kuisioner. Data sekunder diperoleh dari instansi yang menangani jalan pertanian (Dinas Pertanian Tanaman Pangan dan ataupun Dinas Perkebunan) serta laporan lainnya terkait jalan pertanian.

Narasumber (5 orang) yang akan dimintai pendapatnya dalam penyusunan kriteria dan parameter dipilih secara sengaja yang memenuhi salah satu kualifikasi berikut: (1) memahami permasalahan jalan pertanian; (2) bekerja di sektor pertanian, pertanahan, konstruksi ataupun jenis pekerjaan lain yang bersinggungan dengan jalan produksi; (3) pengambil keputusan di instansi pemerintah; atau (4) akademisi/ilmuwan. Selanjutnya data diolah dengan metode Simple Multi Attribute Rating Technique (SMART). Menurut Novianti et al. (2016), SMART merupakan teknik pengambilan keputusan multi kriteria yang didasarkan teori bahwa setiap alternatif terdiri dari sejumlah kriteria dengan nilai-nilai tertentu dan setiap kriteria memiliki bobot yang menunjukkan seberapa penting kriteria tersebut terhadap kriteria lain. SMART merupakan bagian dari metode sistem pendukung keputusan (Decision Support System (DSS)) yang mulai dikembangkan pada tahun 1970. Sistem yang berbasiskan komputer ini dapat meningkatkan kinerja seseorang dalam pengambilan keputusan.

Menurut Eriyatno (2012), DSS dimaksudkan untuk memaparkan secara detail elemen-elemen sistem, sehingga dapat digunakan oleh manajer dalam proses pengambilan keputusan. Terdapat istilah "kriteria" dan "alternatif" dalam DSS dimana "kriteria" menggambarkan tujuan dari sistem dan merupakan basis dalam merancang bangun dan mengembangkan sistem. Sementara istilah "alternatif" menunjukkan kemungkinan tindakan yang harus diambil/dipilih sebagai pilihan terbaik yang sesuai dengan keinginan sistem. Konsep rancang bangun dan pengembangan DSS terdiri tiga elemen utama: (1) pengoptimalan kriteria dalam merancang bangun sistem; (2) proses rancang bangun sistem secara total; dan (3) proses rancang bangun sistem secara mendetail. Proses rancang bangun sistem ini dilakukan secara partisipatif.

Tujuan DSS adalah membantu manajer dalam proses pengambilan keputusan yang umumnya bersifat semistruktural. Teknik ini dikembangkan hanya untuk meningkatkan efektivitas dalam pengambilan keputusan, bukan untuk menggantikan peran manajer itu sendiri. Pada 
langkah awal aplikasi DSS perlu dilakukan analisis keputusan (Decision Analysis) dimana para pengambil keputusan mendefenisikan tentang hal-hal apa yang penting diputuskan. Mereka pasti mampu menentukan aspek-aspek khusus yang dapat diperbaiki dan komponenkomponen apa yang paling mempengaruhi efektivitas keputusan. Aplikasi DSS seharusnya mampu mengintegrasikan berbagai disiplin ilmu melalui pendekatan sistem (Eriyatno, 2012).

Novianti et al. (2016) meringkas urutan penggunaan metode SMART sebagai berikut: (1) menentukan kriteria yang akan digunakan; (2) menentukan bobot pada setiap kriteria dengan menggunakan interval; (3) menghitung normalisasi dari setiap kriteria dengan membandingkan nilai bobot kriteria dengan jumlah bobot kriteria; (4) memberikan nilai parameter kriteria pada setiap kriteria untuk setiap alternatif; (5). menentukan nilai utilitas; dan (6) menentukan nilai akhir masing-masing kriteria dengan mengalihkan nilai yang didapat dari normalisasi nilai kriteria data baku dengan nilai normalisasi bobot kriteria. Selanjutnya nilainilai tersebut dijumlahkan. Persamaan yang digunakan dalam SMART adalah:

Normalisasi bobot kriteria:

$\frac{W_{J}}{\sum W_{J}}$

Dimana $W_{j}$ adalah nilai bobot dari suatu "kriteria" dan $\Sigma W_{j}$ adalah total jumlah bobot semua kriteria.

Nilai utilitas kriteria:

$u_{i}\left(a_{i}\right)=\frac{C_{\text {out }} i-C_{\min }}{C_{\max }-C_{\min }}$

Dimana $u_{i}\left(a_{i}\right)$ adalah nilai utilitas kriteria ke-1 untuk kriteria ke-I, $C_{\max }$ adalah nilai kriteria maksimal, $C_{\min }$ adalah nilai kriteria minimal dan $C_{\text {out }} i$ adalah nilai kriteria ke-i.

Nilai akhir dari masing-masing kriteria :
$U\left(a_{i}\right)=\sum_{j=i}^{m} w_{j} u_{i}\left(a_{i}\right)$

Dimana $U\left(a_{i}\right)$ adalah nilai total alternatif, $\mathrm{w}_{\mathrm{j}}$ adalah hasil dari normalisasi bobot kriteria dan $u_{i}\left(a_{i}\right)$ adalah hasil penentuan nilai utilitas.

\section{HASIL DAN PEMBAHASAN}

Kesulitan yang ditemui dalam penelitian ini menyangkut ketersediaan data jalan pertanian yang tidak tersimpan dengan baik di dinas yang menangani sarana prasarana pertanian. Pergantian pejabat dan/atau restrukturisasi organisasi perangkat daerah dikemukakan sebagai alasan oleh pejabat yang kami hubungi sehingga data tersebut tidak lengkap. Guna mengetahui kondisi terkini jalan pertanian, kami meninjau jalan pertanian yang dibangun sekitar tiga atau empat tahun yang lalu, baik yang berada di kawasan persawahan maupun perkebunan rakyat. Proses pembangunan jalan pertanian dimulai dengan penyusunan petunjuk teknis kegiatan di Dinas Pertanian/Perkebunan setempat yang dilanjutkan dengan seleksi Calon Petani Calon Lokasi (CPCL) berdasarkan proposal dari kelompok tani. Setelah dilakukan penilaian, keputusan calon penerima jalan pertanian ditetapkan melalui surat keputusan Kepala Dinas, yang dilanjutkan dengan penunjukan konsultan perencana yang akan melakukan Survei Investigasi dan Desain (SID) jalan pertanian tersebut. Hasil SID menjadi dasar untuk membangun jalan oleh pihak ketiga yang memenangkan lelang pengerjaan jalan. Setelah konstruksi jalan selesai dan diperiksa oleh panitia pemeriksa barang/jasa, kelompok tani dapat memanfaatkan jalan pertanian tersebut.

Jalan pertanian yang dibangun selama ini masih dapat digunakan oleh masyarakat sekitar, akan tetapi kondisinya tidak terawat dan belum ada yang dikembangkan (diperlebar atau dilakukan penambahan timbunan batu/tanah secara swadana) atau diperbaiki oleh masyarakat sekitar/kelompok tani. Permasalahan menonjol terkait jalan pertanian di Provinsi Jambi disajikan pada Tabel 1.

Tabel 1. Gambaran Masalah Jalan Pertanian di Provinsi Jambi

\begin{tabular}{|c|c|c|}
\hline No & Masalah & Keterangan \\
\hline 1. & $\begin{array}{l}\text { Model jalan } \\
\text { pertanian }\end{array}$ & $\begin{array}{l}\text { Bentuk, lebar dan material pembangunan jalan pertanian bervariasi, disesuaikan dengan } \\
\text { selera kelompok tani, alokasi dana dan pertimbangan lainnya. }\end{array}$ \\
\hline 2. & Perawatan jalan & $\begin{array}{l}\text { Umumnya kondisi jalan bersemak/ditutupi rumput, parit jalan tertutupi batuan/tanah, dan jalan } \\
\text { berlobang serta digenangi air pada musim hujan. }\end{array}$ \\
\hline 3. & $\begin{array}{l}\text { Pemanfaatan } \\
\text { jalan }\end{array}$ & $\begin{array}{l}\text { Belum ditemukan jalan pertanian yang dikembangkan untuk pemanfaatan lain, misalnya untuk } \\
\text { tujuan wisata atau olah raga (jogging track, sepeda dll.) }\end{array}$ \\
\hline 4. & $\begin{array}{l}\text { Konektivitas jalan } \\
\text { pertanian }\end{array}$ & Belum semua jalan pertanian terkoneksi dengan jalan lingkungan desa. \\
\hline 5. & Pendanaan & $\begin{array}{l}\text { Peluang pendanaan terbuka melalui Dana Alokasi Khusus (DAK), tetapi proses pengusulan } \\
\text { melalui e-proposal kurang dikenal/ kurang direspon oleh petani. }\end{array}$ \\
\hline 6. & $\begin{array}{l}\text { Alih fungsi lahan } \\
\text { pertanian }\end{array}$ & $\begin{array}{l}\text { Meskipun belum menjadi gejala masif, akan tetapi ditemukan lahan yang telah beralih fungsi di } \\
\text { kawasan pertanian yang dibangun jalan pertanian. }\end{array}$ \\
\hline 7. & Daya tahan jalan & $\begin{array}{l}\text { Jalan pertanian di lahan gambut lebih cepat rusak (mudah amblas) dibandingkan jalan di atas } \\
\text { lahan mineral. Belakangan ini, jalan pertanian di lahan gambut dibangun dengan konstruksi } \\
\text { rigid beton dengan alokasi dana dua kali lebih besar dibanding konstruksi jalan di lahan } \\
\text { mineral. }\end{array}$ \\
\hline 8. & Skema & $\begin{array}{l}\text { Pengerjaan jalan pertanian lewat APBD Provinsi atau kabupaten dilakukan dengan menunjuk } \\
\text { pihak ketiga, sedangkan untuk dana APBN (DAK) dikerjakan secara swakelola. }\end{array}$ \\
\hline
\end{tabular}

Pemanfaatan jalan pertanian di Provinsi Jambi belum berkembang untuk tujuan lain, seperti wisata dan olahraga, walaupun beberapa daerah berpotensi dikembangkan untuk tujuan tersebut, misalnya di Kabupaten Kerinci, Kota Sungai Penuh dan Kabupaten Merangin. Daerah-daerah ini memiliki keindahan alami wilayah dan topografi yang sesuai 
untuk olahraga maupun wisata pertanian kopi, kayu manis dan hortikultura. Kondisi tersebut berbeda dengan daerah di Bali, dimana jalan pertanian telah dimanfaatkan untuk mendukung agro-ekopariwisata berbasis sistem subak (Artawan dan Sunarta, 2016).

Membangun konektivitas antar jalan pertanian dengan jalan lingkungan, ataupun dengan jalan kabupaten cukup sulit. diwujudkan di kabupaten/kota di Provinsi Jambi karena belum adanya perencanaan yang matang. Kondisi ini berbeda dengan kondisi di Kabupaten Sidoarjo yang berdasarkan penelitian Hardaningrum (2015) menyatakan bahwa pembangunan ruas jalan produksi perikanan didasarkan pada pertimbangan kriteria: (a) rute lintasan pelaku usaha perikanan (pemilik tambak, petani tambak, jalur pemasaran komoditi); (b) kondisi lebar dimensi dan kesiapan jalan yang ada untuk dikembangkan; (c) usulan prioritas rute jalan yang dihasilkan dari forum partisipasi masyarakat; dan (d) koneksitas rute/ruas jalan terhadap simpul strategis perikanan dan program sektoral. Keinginan pemerintah daerah untuk memperpanjang jalan pertanian di desa-desa dengan anggapan akan meningkatkan konektivitas ke pasar atau wilayah lain, seharusnya dipertimbangkan dengan hati-hati karena panjangnya jalan tidak selalu sebanding dengan peningkatan konektivitas antar wilayah. Hasil penelitian Patarasuk (2013) menunjukkan bahwa meskipun total panjang jalan di Provinsi Lop Buri, Thailand meningkat, tidak berarti konektivitas juga meningkat. Hal ini bergantung bagaimana jalan tersebut dikembangkan, apakah menghubungkan jalan yang ada atau dikembangkan sebagai ujung buntu. Analisis statistik menjelaskan bahwa pengembangan jaringan jalan dapat mempengaruhi jumlah tutupan lahan seiring berjalannya waktu, termasuk lahan padi dan tanaman dataran tinggi, hutan dan area terbangun. Penelitian ini menunjukkan bagaimana indeks jaringan jalan dan jumlah jalan mempengaruhi tutupan lahan serta menegaskan bahwa konektivitas jalan diduga tidak lebih penting dari jumlah jalan.

Wawancara mendalam dengan narasumber terpilih menyepakati kriteria pemilihan lokasi pembangunan jalan pertanian beserta parameter masing-masing kriteria sebagaimana disajikan pada Tabel 2.

Tabel 2. Kriteria dan Parameter Untuk Setiap Kriteria Jalan Pertanian

\begin{tabular}{lll}
\hline No & \multicolumn{1}{c}{ Kriteria } & \\
\hline 1 & Lokasi & 1. Kontur lahan rata/sesuai \\
& & 2. Jalan telah dirintis oleh masyarakat \\
& & 3. Terhubung dengan jalan lingkungan/kabupaten \\
& 4. Berada di kawasan pertanian sesuai RT/RW
\end{tabular}

Dengan menggunakan persamaan (1) diperoleh bobot untuk masing-masing kriteria sebagaimana disajikan pada Tabel 3.

Tabel 3. Kriteria dan Bobot Masing-Masing Kriteria

\begin{tabular}{lc}
\hline \multicolumn{1}{c}{ Kriteria } & Normalisasi Bobot \\
\hline Lokasi & 0,23 \\
Kelompok tani & 0,36 \\
Kualifikasi kebun/ sawah & 0,24 \\
Sharing dalam perawatan & 0,17 \\
jalan pertanian & \\
\hline Total & 1,00 \\
\hline
\end{tabular}

Dari Tabel 3 terlihat bahwa bobot penilaian tertinggi diberikan kepada kriteria kelompok tani. Kekompakan dan keaktifan kelompok dinilai lebih tinggi dari kriteria lainnya. Menurut narasumber, pertimbangan ini berlaku untuk semua jenis bantuan/hibah pemerintah. Menurut Fatchiya (2010), kelompok mempunyai fungsi sebagai tempat pembinaan bagi anggotanya dan wadah proses belajar bersama, sehingga dapat memudahkan penyuluh dalam menyelenggarakan kegiatan penyuluhan serta terbentuknya tanggung jawab bersama atas program bantuan yang diberikan. Menurut Mutmainah dan Sumardjo (2014), selain hibah atau bantuan pemerintah harus diberikan lewat wadah kelompok, pemberdayaan petani juga lebih efektif dilakukan melalui kelompok tani. Klasifikasi kelompok tani berdasarkan Permentan Nomor 82 Tahun 2013 dapat menjadi acuan tingkat keberdayaan petani dalam melaksanakan usaha tani, termasuk dalam mengelola bantuan yang diberikan pemerintah (dalam hal ini jalan pertanian). Dalam Permentan ini, dijelaskan bahwa kemampuan kelompok tani dan gabungan kelompok tani diklasifikasikan menjadi 4 kategori, yaitu kelas pemula, kelas lanjut, kelas madya, dan kelas utama.

Dari pembobotan kriteria di atas, sharing dalam perawatan jalan pertanian mendapat bobot yang terendah. Meskipun narasumber terpilih mengakui pentingnya partisipasi masyarakat dalam merawat jalan pertanian, pembebanan tanggung jawab perawatan seharusnya dibagi antara pemerintah, kelompok tani dan anggota masyarakat lain yang menggunakan jalan pertanian tersebut. Khusus untuk jalan perkebunan sawit dan karet, kelompok tani di 
lokasi penelitian biasanya meminta partisipasi pemilik truk (pedagang pengumpul) hasil sawit/karet karena mereka juga menikmati manfaat jalan tersebut. Berdasarkan penelitian Gusnawaty (2013) dengan menggunakan model IO menunjukkan bahwa sektor komoditas perkebunan yang paling terpengaruh oleh investasi di sektor jalan, jembatan, dan pelabuhan adalah sektor karet dan sektor kelapa sawit.

Selanjutnya untuk memudahkan pengambil keputusan memberikan nilai terhadap calon lokasi jalan pertanian, disusun konfigurasi nilai kriteria seperti dimuat dalam Tabel 4.

Tabel 4. Konfigurasi Nilai Kriteria

\begin{tabular}{|c|c|c|}
\hline Kriteria & Parameter & $\begin{array}{c}\text { Nilai Parameter } \\
\text { Kriteria }\end{array}$ \\
\hline Lokasi & $\begin{array}{l}\text { - sangat sesuai (memenuhi lebih dari } 3 \text { parameter) } \\
\text { - sesuai (memenuhi 2-3 parameter) } \\
\text { - kurang sesuai (hanya memenuhi } 1 \text { parameter atau tidak sama sekali) }\end{array}$ & $\begin{array}{l}3 \\
2 \\
1\end{array}$ \\
\hline Kelompok tani & $\begin{array}{l}\text { - sangat sesuai (memenuhi lebih dari } 3 \text { parameter) } \\
\text { - sesuai (memenuhi 2-3 parameter) } \\
\text { - kurang sesuai (hanya memenuhi } 1 \text { parameter atau tidak sama sekali) }\end{array}$ & $\begin{array}{l}3 \\
2 \\
1\end{array}$ \\
\hline Kualifikasi kebun/ sawah & $\begin{array}{l}\text { - sangat sesuai (memenuhi lebih dari } 3 \text { parameter) } \\
\text { - sesuai (memenuhi 2-3 parameter) } \\
\text { - kurang sesuai (hanya memenuhi } 1 \text { parameter atau tidak sama sekali) }\end{array}$ & $\begin{array}{l}3 \\
2 \\
1\end{array}$ \\
\hline $\begin{array}{l}\text { Sharing perawatan jalan } \\
\text { pertanian }\end{array}$ & $\begin{array}{l}\text { - sangat sesuai (memenuhi lebih dari } 3 \text { parameter) } \\
\text { - sesuai (memenuhi 2-3 parameter) } \\
\text { - kurang sesuai (hanya memenuhi } 1 \text { parameter atau tidak sama sekali) }\end{array}$ & $\begin{array}{l}3 \\
2 \\
1\end{array}$ \\
\hline
\end{tabular}

Dengan menggunakan persamaan (2), dilakukan perhitungan nilai utilitas untuk masing-masing parameter "sangat sesuai", "sesuai" dan "kurang sesuai", sebagaimana disajikan pada Tabel 5 .

Mengacu kepada bobot masing-masing kriteria dan nilai utilitas parameter kriteria, pengambil keputusan dapat memutuskan dengan cepat dan lebih objektif terhadap alternatif lokasi pembangunan jalan pertanian dengan mengalikan bobot kriteria dengan nilai utilitas parameter kriteria, seperti ditunjukkan pada persamaan (3).

Tabel 5. Konfigurasi nilai utiliti parameter kriteria jalan pertanian

\begin{tabular}{ccccc}
\hline Nilai Parameter Kriteria & Parameter & $\mathrm{C}_{\text {out }}-\mathrm{C}_{\min }$ & $\mathrm{C}_{\max }-\mathrm{C}_{\min }$ & Nilai utilitas kriteria \\
\hline $1=$ & Kurang sesuai & 0 & 2 & 0 \\
$2=$ & Sesuai & 1 & 2 & 0,5 \\
$3=$ & Sangat sesuai & 2 & 2 & 1 \\
\hline
\end{tabular}

\section{KESIMPULAN DAN SARAN}

\section{Kesimpulan}

Terdapat delapan permasalahan utama terkait jalan pertanian di Provinsi Jambi yang menyangkut aspek pendanaan dan aspek teknis lainnya, seperti konektivitas, pemanfaatan jalan untuk tujuan lain yang memberi nilai tambah (wisata atau olahraga), partisipasi kelompok untuk merawat jalan hingga pola pengerjaan dan model jalan yang belum baku sehingga mempengaruhi kualitas jalan yang dibangun. Berdasarkan 4 kriteria yang ditetapkan untuk menentukan lokasi pembangunan jalan pertanian, kriteria kelompok tani memperoleh bobot yang paling tinggi, sedangkan sharing perawatan jalan mendapat bobot yang terendah. Rendahnya bobot untuk sharing perawatan jalan tidak berarti bahwa kriteria ini tidak penting. Hal ini didasarkan pada kemampuan kelompok tani yang rendah untuk membiayai perawatan jalan pertanian di wilayahnya.

\section{Saran}

- Dinas yang menangani fungsi pertanian pangan/hortikultura dan perkebunan disarankan melakukan penilaian proposal jalan pertanian dengan mempertimbangkan 4 kriteria dan pembobotan terhadap setiap kriteria (lokasi, kelompok tani, kualifikasi kebun/sawah dan sharing perawatan jalan) sebagai dasar untuk penentuan lokasi pembangunan pertanian.

- Perencanaan jalan pertanian harus mempertimbangkan konektivitas antar jalan yang ada dengan jalan pertanian yang akan dibangun agar optimalisasi transportasi input dan output pertanian, serta efisiensi dana pemerintah tercapai.

- Dana desa dapat dimanfaatkan untuk membangun jalan pertanian. Pemerintah desa disarankan berkoordinasi dengan dinas yang menangani fungsi pertanian pangan/hortikultura dan perkebunan terkait juknis/juklak, model jalan serta skema pengerjaan yang tepat (swakelola oleh kelompok tani atau menggunakan jasa pihak ketiga).

- Aturan yang mengikat tentang sharing perawatan jalan pertanian disarankan menjadi bagian dari berita acara atau kontrak kerjasama dengan petani, masyarakat setempat (yang lokasinya terpilih untuk pembangunan jalan pertanian) ataupun pihak swasta yang ikut memanfaatkan jalan pertanian tersebut. Hal ini bertujuan untuk menumbuhkan rasa tanggung jawab terhadap pemeliharaan jalan pertanian yang bersumber dari dana pemerintah.

- Pembangunan jalan usaha tani lebih diprioritaskan pada kawasan Lahan Pertanian Pangan Berkelanjutan (LP2B), sekaligus untuk mendorong perluasan kawasan LP2B di Provinsi Jambi, kecuali untuk wilayah perkotaan yang sulit menemukan kawasan pertanian dalam hamparan yang cukup luas.

- Pemerintah kabupaten/kota disarankan melakukan peningkatan kualitas jalan pertanian dari konstruksi tanah, melalui proses pengerasan jalan atau pembetonan untuk jalan pertanian yang telah dimanfaatkan cukup lama dan terawat dengan baik 
sebagai penghargaan bagi kelompok tani/masyarakat setempat.

- Pemerintah kabupaten/kota agar memperketat regulasi yang melarang alih fungsi lahan pertanian di kawasan yang sebelumnya telah didanai pembangunan jalan pertaniannya.

\section{UCAPAN TERIMA KASIH}

Penulis menyampaikan ucapan terima kasih kepada Kepala Badan Litbangda Provinsi Jambi Ir. Azrin, M.Si, rekan Ir. Mukhlis M.Si dan Adi Rahman S.E.,ME. dan Suharman S.E.,ME. serta pendamping lapangan yang telah mendukung dan membantu pelaksanaan penelitian ini.

\section{DAFTA PUSTAKA}

Aggarwal S. (2018). Do Rural Roads Create Pathways Out of Poverty? Evidence from India. Journal of Development Economics, 133 (2018), 375-395.

Artawan IMJ, dan IN Sunarta. (2016). Strategi krama subak dalam menanggulangi alih fungsi lahan pertanian akibat pariwisata (studi kasus subak umadesa Desa Lodtunduh, Ubud). Jurnal Destinasi Pariwisata, 4, 134138.

Dercon S. (2005). Risk, Poverty and Vulnerability in Africa. Journal of African Economies, 14 (4), 483-488.

Eriyatno. (2012). IImu Sistem. Meningkatkan Mutu dan Efektivitas Manajemen. Surabaya: Guna Widya.

Fatchiya A. (2010). Pola pengembangan kapasitas pembudidaya ikan kolam air tawar di Provinsi Jawa Barat. Disertasi, Institut Pertanian Bogor, Bogor.

Gusnawaty N. (2013). Analisis dampak ekonomi infrastruktur jalan terhadap sektor perkebunan di Provinsi Lampung. Tesis, Institut Pertanian Bogor, Bogor.

Hardaningrum F. (2015). Pengembangan jalan produksi perikanan di Kabupaten Sidoarjo. e-Jurnal Spirit Pro Patria, 1 (1), 9-18. doi: E-ISSN 2443-1531

Mutmainah R, dan Sumardjo. (2014). Peran kepemimpinan kelompok tani dan efektivitas pemberdayaan petani. Sodality: Jurnal Sosiologi Pedesaan, Desember 2014, 213-232.

Novianti D, IF Astuti, dan DM Khairina. (2016). Sistem Pendukung Keputusan Berbasis Web Untuk Pemilihan Café Menggunakan Metode Smart (Simple MultiAttribute Rating Technique) (Studi Kasus Kota Samarinda). Paper dipresentasikan pada Seminar Sains dan Teknologi FMIPA Universitas Mulawarman, Samarinda, Indonesia.

Patarasuk R. (2013). Road network connectivity and landcover dynamics in Lop Buri province, Thailand. Journal of Transport Geography, 28 (2013), 111-123.

Posumah F. (2015). Pengaruh Pembangunan Infrastruktur Terhadap Investasi Di Kabupaten Minahasa Tenggara. Jurnal Berkala IImiah Efisiensi, 15 (02), 113.

Siregar H, dan H Hasanah. (2011). Infrastruktur Sebagai Pilar Pembangunan Pertanian Yang Efisien. Agrimedia, 16, 4-10.

Tarigan SD, dan R Syumanjaya. (2013). Analisis Pengaruh Kualitas Infrastruktur Jalan Terhadap Harga-Harga Hasil Pertanian Di Kecamatan Dolok Silau. Jurnal Ekonomi dan Keuangan, 1 (6), 70-83.

Zakaria AK. (2010). Program Pengembangan Agribisnis Kedelai Dalam Peningkatan Produksi dan Pendapatan Petani. Jurnal Litbang Pertanian, 29 (4), 147-153.
Zhang X, G Wan, dan X Wang. (2017). Road infrastructure and the share of labor income: Evidence from China's manufacturing sector. Economic Systems, 41 (2018), 513-523. 